\title{
The Effect of Transparency on Brand Loyalty
}

\author{
Irkhamnah Aisyah Yuana and Yudi Sutarso \\ Department of Management, STIE Perbanas Surabaya, Surabaya \\ e-mail:2017610905@students.perbanas.ac.id
}

\begin{abstract}
Bank needs to provide best services to minimize customer's complaint. One of bank efforts to serve their customers can be done by using transparency, so that all information is conveyed clearly. Transparency is also expected to enhance brand loyalty of customers. This conceptual study is based on theoretical review from literatures and previous researches related with these concepts. The basic concept of theory used in this study is that customers who get operational transparency express greater trust and support. This study aimed to analyze the effect of transparency on brand loyalty. By classifying the result of previous researches, this study found some propositions : (1) transparency has a significant effect on brand trust of customer; (2) brand trust has a significant effect on brand satisfaction of customer (3) brand trust has a significant effect on brand loyalty.
\end{abstract}

Keywords-Transparency, Brand Trust, Brand Satisfaction, and Brand Loyalty.

\section{INTRODUCTION}

$\mathrm{B}^{\mathrm{n}}$ RAND, now is a matter of public concern. It's not something new for people to remember a service based on their brand. One of the service companies that has always been a concern from the public is bank. If a customer has chosen one of all banks to be an alternative that can help sustain the business by providing loans in the form of credit. Many benefits will be provided by the bank, it may be concerned if it is success in providing the best alternative promotions and ultimately getting customers.

The bank will also try to keep their customers from switching to other banks or even giving a negative impression about the bank to other parties. Banks often do many things to attract the attention of the public so they are willing to become their customers and with good service will provide satisfaction which can further make them to be loyal customers. This statement is in accordance with the research of Putri and Iwan which explains that quality gives encouragement to customers to establish close relationships with the company so that it allows the company to understand carefully about the expectations and needs, which ultimately, customer satisfaction can create loyalty to company [1]. The benefits that can certainly be felt by the bank are customer's loyalty which of course will not be easily move to other banks and also later it will be easier for banks to get new funds from the party recommended. In addition, banks also get benefits in the form of cost pressures on loyal customers. This was explained that by considering the cost reduction effect, it was reported that while maintaining customer loyalty would incur less costs than obtaining a new customer and the cost to retain customers decreased throughout the life cycle phase of the relationship [1]. Various efforts will be made by the bank because it is considered retaining loyal customers. It will be a challenge and its presence is important as an evaluation of the performance of the bank.
Customers become loyal because of the service, the tendency is because they are satisfied with the services provided. If the customer feels the service from the bank is better or equal to their expectations, the customer will feel satisfaction. According to Tatik Suryani, consumers, either directly or indirectly will certainly provide an assessment of the services purchased or ever consumed. The evaluation is based on an overall assessment of what is received and experienced compared to what was expected [2]. There are two main factors that serve as consumer guidelines, namely: the service received, and the service expected. From this satisfaction, customers can later become loyal customers Conversely, when customers feel that the services provided are not in line with what they've expected before, customers will feel dissatisfied and they will not re-purchase or use the bank's services for the second time.

Consumers will assess a service deeper if they have used or felt the service. Unconsciously, consumers will judge a product or service directly when they begin to use it or feel it. Especially when customers are in banking industry, they will directly meet the employees who have the authority to handle these customers. In banking industry, for those who have the authority to handle customers directly is Front liner. Therefore, they will have a interaction and conversation according to what customer needs and also the information provided by the front liners so as to create satisfaction felt by the customers. This is in accordance with the research that services are not only able to fulfill information and provide solutions to customer problems, but also must be able to satisfy customers far above their expectations. In other words, there will be an intensity to communicate between customers and bank employees. This communication is certainly not limited only because customers have needs that will later have to be provided by the selected bank. But also it will be many models of services provided by the bank in relation to improving the quality and perception of customers in providing an assessment. This assessment will become the bank's expectation that customers feel satisfaction and therefore, the customers will be loyal to the bank.

Communication between bank employees and customers is a matter of great concern, the selection and decision making of customers can also be determined after the communication in the form of an explanation of some things needed by the customer. Communication skills or abilities are one of the factors that affect service quality and customer satisfaction levels. With good communication skills, the communication that is established will be effective. Communication can be said to be effective if the message delivered can be received and understood as intended by the sender of the message. While from the bank's employees, of course the best service will be provided to customers and for the convenience of customers, in its service the bank will provide an explanation of the product to be selected. 
The $1^{\text {st }}$ International Conference on Business and Engineering Management (IConBEM)

February $1^{\text {st }} 2020$, Institut Teknologi Sepuluh Nopember, Surabaya, Indonesia

In addition, customers will be given education about risks. Certainly the bank will emphasize that the risk will never be equal with zero, but at least it can be minimized and it becomes important for the convenience of customers. A good bank is certainly a bank that provides information to customers transparently without being covered but is still at a normal level and does not reveal secrets or important things in the company. With good and effective communication between front liners and customers, the information needs and solving problems faced by customers will be easily achieved. Conversely, if the front liner does not perform their role properly, then the communication that is established becomes ineffective so that it can lead to miscommunication.

\section{A. Transparency}

Transparency is defined as how people feel that they need information about several aspects of trustworthiness of funds that enable them to observe what happens under conditions of entrusting fund storage, to influence income expenditure, and to evaluating the performance of funds that have been felt [3]. This information must not only be publicly available, but also needs to be understood, relevant and accessible, which in turn allows the substantive adjustment of information asymmetry between the trust of the public to give up funds for safekeeping. This provides potential information to act as a basis for forming or changing views about the management of funds by community members. Muslu's research explains that there is considerable empirical variation between companies when discussing transparency in disclosure of compensation [4]. Jagolinzer's research (2009) states that in some cases, disclosure of compensation compensation and in other cases is unclear. For an empirical analogue to our definition of transparency, consider the plan adopted by the company. This plan allows people in the company to commit to a trading plan where they pre-commit to sell or buy their company's securities in a certain way with the aim of preventing insider trading claims. Albu and Flyverbom defined that Transparency is an increasingly prominent area of research that offers valuable insights for studies [5].

However, conceptualizations of transparency are rarely subject to critical scrutiny and thus their relevance remains unclear. In most accounts, transparency is associated with the sharing of information and the perceived quality of the information shared [6]. This narrow focus on information and quality, however, overlooks the dynamics of organizational transparency. Transparency addresses the fishbowl nature of executing customer service in the age of the internet. That is, all customer comments and firm responses are free for the world to see, emphasizing the need for firms to consider not only the initial poster's complaint, but also other consumers that may view the complaint. Weller defined that transparency and Privacy Indeed, in many cases, transparency may be viewed as the opposite of privacy [7]. Many in society feel that some sort of right to privacy- and hence, a limit to transparency - is appropriate [7], [8]. Indicators to measure the Transparency variable, adopted from the research of Yudi Sutarso et al., (2017), namely:

1. Full disclosure of information

2. Free access to information.

3. Partnership and sharing information

4. Full disclosure of information on cost and prices

\section{B. Brand Trust}

Trust is defined in Hobbs \& Goddard (2015) research in Portal, Abratt, Bendixen (2018) explaining in the science of sociology, trust has been organized into broad categories; that is, institutional trust (trust in regulatory bodies), general trust (trust in others), calculative trust (trust based on rational evaluation), and relational trust (trust is obtained from time to time and through interaction) [9]. Added in the study of Chaudhuri \& Holbrook, (2001); Delgado-Ballester \& Luis Munuera-Alemán, (2001) Brand trust develops over time, through direct experience and occurs in the context of a relationship [9]. Therefore, it may be more closely related to a relationship of trust. Trust is defined as a willingness to accept vulnerability based on positive expectations regarding the intentions and behavior of others [9]. Chaudhuri and Holbrook (2001) in their research that brand trust is described as the will of consumers solely because it relies on the brand's ability to fulfill its promises. Ability is based on positive expectations regarding the intentions and behavior of others. Ferrinadewi (2008) explains that the process of creating trust in a brand is based on consumer experience in the consumer experience of the brand used [10].

Experience is a source for consumers to create trust in the brand. This experience will affect consumer evaluations in consuming or satisfaction directly and indirect contact with consumers. Dai, Qin, Ma defined that brand trust is one of the ways that enterprises do to influence consumers' attitude towards their own brand, while public service marketing can effectively show the positive image of enterprises, to improve consumers' high trust in enterprises or their products [11]. Dai, Qin, Ma also said that Brand trust is a multi-level, multidimensional concept, which is a kind of recognition and trust of consumers to enterprises [11]. Brand trust is a commitment of the company to show its unique personality to consumers, so that consumers understand that the core values of the company are "customer-oriented, service oriented". If a company or brand wants to gain the trust of consumers, it must first consider whether it can be psychologically recognized by consumers. With the continuous development of interactive media, diversified communication methods, and the increasing demand of consumers, it is not only the pursuit of material satisfaction brought by products and services, but also the satisfaction of enterprises in the spirit. And public welfare marketing is an effective marketing model that can be widely recognized and trusted by the public. Clarke et al., (2012) in Venter, Chinomona, and Chuchu defined that cognitive trust refers to brands or retailers that are confident in their competency and reliability in keeping promises, while affective trust is the belief that while the customers seek to buy genuine, stylish, and modern products, they also have specific requirements [12]. Indicators to measure the Brand Trust variable, adopted from the research of Moreira, et al (2017), namely [13]:

1. Based on my experience, I know this supplier is honest.

2. Based on my experience, I know this supplier is not opportunistic.

3. Based on my experience, I know this supplier cares about its customers

\section{Brand Satisfaction}

Satisfaction is explained by Tse and Wilton (1988, p. 204) in Mabkhot, Salleh and Shaari (2016) that satisfaction is 
The $1^{\text {st }}$ International Conference on Business and Engineering Management (IConBEM)

February $1^{\text {st }} 2020$, Institut Teknologi Sepuluh Nopember, Surabaya, Indonesia

defined as "consumer response to evaluation of perceived differences between previous expectations and actual product performance as perceived after consumption" [14]. Interpreted in another study by Westbrook and Reilly (1983) in Mabkhot, Salleh and Shaari (2016) that is defined as "emotional responses to experiences provided by or related to certain products or services purchased, retail outlets, or even molar behavior patterns such as shopping and buyer behavior, and the market as a whole" [14]. Zhao explained that brand satisfaction is an evaluation of consumers for products or services purchased throughout the market, and is an emotional response after comparing with their values (exp. needs, wants) [15].

Philip Kotler (1996) argues that satisfaction is a state of pleasure or disappointment shown by consumers after comparing the perceived effect of a product with its expectations. Other research is also described in Oliver who believes that brand satisfaction is a psychological state, evaluation and feedback of products or services, and the end result of all behavior in the entire consumption process [12]. According to Rowley (2009) states that brand satisfaction is defined as the extent of customer expectations relating to the meeting of products or service brands [13]. Satisfied customers can develop loyalty, intention or desire to buy back a brand. It is expected that later if service providers can meet the needs of their customers better than competitors, so as to make it easier for customers to be loyal.

As with consumer loyalty, consumer satisfaction contains the subcategory of brand satisfaction. Whereas consumer satisfaction describes the consumer's feeling towards an object or service in general, brand satisfaction describes satisfaction towards brands in particular [16]. Kusuma's research explains that brand satisfaction is the customer's response to the actual quality of a product and the expectations desired by previous customers after consumers consume them [17]. The creation of customer satisfaction with a product is based on the desire of consumers who are satisfied with a brand that can provide benefits. If a brand can be trusted by consumers, it will indirectly guarantee the satisfaction. Indicators to measure the Brand Satisfaction variable, adopted from Eric's research (2018), namely [17]:

1. Consumer's response to the quality of a product in actuality.

2. Expectation desired by previous consumers after customer consume it.

3. Customer's satisfaction of a product is based on the desire of consumers who are satisfied by a brand that can provide benefits.

4. If a brand can be trusted by consumers then indirectly will provide satisfaction guarantee.

\section{Brand Loyalty}

Loyalty is defined as the level of consumer loyalty to certain brands, regardless of competitive brand marketing activities [18]. In the condition that consumers like certain products can have an impact on consumers' decisions to remain on the same product or not, and when consumers decide to use the same product, they automatically become loyal customers so that they do not need much consideration if they will buy the same product for both times even for more frequent intensity. Loyalty can be indicated by the existence of consumers who not only buy products or services, but also those who have good commitment and behavior by serving the company by recommending others to buy products or the same service they bought [10]. Consumers with a high level of brand loyalty, tend to repurchase products with the same brand, or continue to use products or services provided by certain brands for a long time [12]. They still do it despite changes in the product/service, price increases, changes in the way the product/service is packaged, and other possibilities that can occur. Unlike those who have a low level of loyalty, if there are changes to the product/service, then they tend to move and try other brands. Gozukara and Colakoglu said that brand loyalty can also reduce marketing communication expenses as sales campaigns or advertisements are less required with loyal customers relative to those with low levels of loyalty since such customers already possess a purchase decision [19].

Furthermore, customers who are loyal and satisfied start to promote the brand, which leads to word-of-mouth communication and increased numbers of prospective customer. As consumers continue to come back for the same products, they start believing each product produced by that specific brand contains a unique quality that no other brand can give them [20]. Pappu and Quester described that highquality perceptions provide a strong reason for consumers to be loyal to a brand [21]. Brands that fail to signal high quality are thus unlikely to translate the benefits of high innovativeness into consumer brand loyalty. [23] Gaining customer loyalty is an important objective of strategic marketing and relationship marketing initiatives [22]. Customer loyalty is critical for business to gain competitive advantage. Loyalty can provide essential benefits for both consumers and companies. For consumers, a brand toward which they feel loyal, can act as a signal of achieved expectation. Because of familiar and favorable signal that a brand sends consumers buy the brand with more comfort believing that the brand will meet their expectations. This comfort would mostly come from the credibility of the brand established from past experiences. That is, quality is a necessary condition for innovativeness perceptions toward a brand to translate into loyalty. In addition, brand loyalty prevents sales churn and has a positive effect on the business retention. Brand Loyalty is associated with users' repeated buying behavior over time with positive, evaluative, and/or biased tendencies towards branded alternatives labeled or multilevel or product choices [23].

Indicators to measure the Brand Loyalty variable, adopted from the research of Mohd Suki (2015), namely [23]:

1. I am satisfied with product/brand that appeared in the social media.

2. I would recommend this particular product/brand to others through the social media.

3. I will not switch to another product/brand that appeared in the social media next time.

4. I usually use this particular product/brand as my first choice in comparison with the other product/brand.

5. I regularly refer this particular product/brand through the social media

In this study, researchers proposed the following thoughts:

a. Transparency has a positive effect on Brand Trust of customers. 
The $1^{\text {st }}$ International Conference on Business and Engineering Management (IConBEM)

February $1^{\text {st }} 2020$, Institut Teknologi Sepuluh Nopember, Surabaya, Indonesia

b. Brand Trust has a positive effect on Brand Satisfaction of customers.

c. Brand Trust has a positive effect on Brand Loyalty of customers.

\section{METHOD}

This study is based on a conceptual model of transparency and brand trust in terms of influencing brand satisfaction and brand loyalty. This study produced a conceptual model of customer transparency and brand trust in terms of brand satisfaction and brand loyalty in the use of consumer credit services. According to previous literature, researchers have found several factors that affect transparency, brand trust, brand satisfaction and brand loyalty. Reference is taken from the study of several books and journals. Therefore, to understand the factors that affect transparency, brand trust, brand satisfaction and brand loyalty, researchers conduct primary data collection, then compare and analyze.

\section{RESULT AND DISCUSSION}

The results of this study are refer to several journals that researchers have used as a reference. The researcher uses the variables of transparency, brand trust, brand satisfaction and brand loyalty as variables to be examined because it refers to previous studies that have obtained the results of influence between these variables which are then summarized by researchers for further research.

\section{A. The Effect Of Transparency On Brand Trust}

Transparency is defined as how people feel they need information about several aspects of trust funds that enable them to observe what happens under conditions of entrusting fund storage, to influence revenue expenditure, and to evaluate performance funds that have been felt [3]. This transparency is expected to be an important point to provide security for consumers so as to increase consumer brand trust. Portal et al., describe brand trust as the willingness of consumers to rely on the brand's ability to fulfill its promises [9]. This is in line with the results of research from Kim and Lee's research which says that current studies explore how transparency efforts undertaken by organizations can be effectively communicated in relation to the causes of companies wanting to increase trust and increase organizational advocacy while reducing organizational doubt from stakeholders [24].

From this research the researchers concluded that by using aspects of transparency, the company can increase brand trust in consumers and this has a good impact on the company because it is considered to be able to help provide solutions to consumers and also has a good impact on consumers because they have received the information needed. Corporate information transparency is the relative degree to which market participants have easy access to all of the company's information [25]. Corporate information transparency can improve consumer brand trust level, high corporate information transparency can alleviate consumers' negative perception of crisis events and reduce corporate moral hazard [26]. The level of a company's transparency, as perceived by a consumer, especially in addressing sweatshop issues and/or labor conditions, can play a valid and significant role in building trust and positive attitude toward the company. Trust and positive attitudes built between the company and the consumer due to transparency about CSR efforts can be linked to the consumer's intent to consider a purchase from the company as well as to deliver a positive opinion to others.

Consumers' perception of a corporation's efforts to be transparent about production and labor conditions and to be socially responsible by giving back to the local community plays a critical role in building consumers' trust and positive attitude toward the corporation and in turn developing their intentions to purchase from the corporation and spread positive WOM about the corporation and its products. From some of the research results that have been elaborated by researchers, the researchers concluded that in terms of providing information and services, companies must provide important points in the form of transparency. This is because from several previous studies revealed that consumers tend to be more happy if the company provides complete, and also clear information. Not only information about the flow/process but also related to price. Consumers who get complete information and also as expected will have an impact in the form of trust in the brand. This trust will also benefit the company because, as mentioned by previous research, when viewed from a cost perspective, compared to utilizing old customers, finding new customers will cost more. Therefore the company must be able to pay attention to the information provided to consumers in order to meet consumer needs and not move to other brands.

\section{Preposition 1: Transparency has a significant effect on Brand Trust of Customers}

\section{B. The Effect Of Brand Trust On Brand Satisfaction.}

The impact that occurs with this brand trust is increased brand satisfaction. Brand satisfaction itself is interpreted as explains that brand satisfaction is the customer's response to the actual quality of a product and the expectations desired by previous customers after consumers consume them [17]. The Research of Simon, Devi, Aditya which explains that with the quality of service that is supported by brand trust by consumers, will deliver to customer satisfaction [27]. Therefore the company will always provide services that can support the trust of the brand to consumers, so as to deliver consumers to satisfaction. Described in the research of Tatik Suryani, consumers, either directly or indirectly will certainly provide an assessment of the services purchased or ever consumed[2].

The evaluation is based on an overall assessment of what is received and experienced compared to what was expected. There are two main factors that serve as consumer guidelines, namely: the service received, and the service expected. If the results received are more than expected, then the consumer will feel satisfied. Conversely, if consumers feel that the results received are less than expected, then consumers will feel dissatisfied. From the results of the study that have been described by researchers, the researchers concluded that brand trust affects brand satisfaction. Brand trust here can affect brand satisfaction because consumers have given trust to certain brands which means consumers have felt the product/service, so that when using the same brand, consumers will feel satisfaction. Consumers who believe in a 
The $1^{\text {st }}$ International Conference on Business and Engineering Management (IConBEM)

February $1^{\text {st }} 2020$, Institut Teknologi Sepuluh Nopember, Surabaya, Indonesia

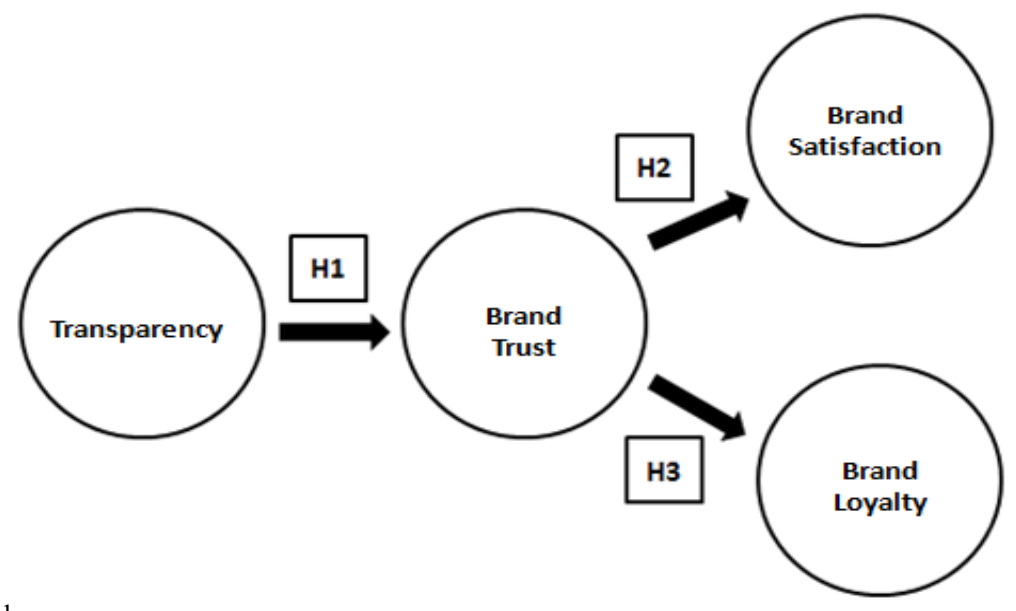

Figure 1. Conceptual Framework

brand tend to think twice if they want to change choices to other brands.

As explained from the previous research, the researchers conclude that satisfied consumers are consumers who get products/services from a company more than what consumers expect, consumers will automatically feel the advantages of what consumers have expected so as to cause feelings of pleasure and lead to on satisfaction. From brand trust, consumers will feel satisfied because consumers feel accustomed to using these products/services.

Preposition 2 : Brand Trust has a significant effect on Brand Satisfaction of Customer.

\section{The Effect Of Brand Trust On Brand Loyalty.}

Brand trust can also be used as a factor for consumers to feel loyal to a brand [28]. Loyalty has been defined by the American Marketing Association in Fouzia Ali and Salma Muqadas as "a situation where consumers generally buy products or services from the same factory repeatedly over time rather than buying from multiple suppliers" . Providing services that can support brand trust to consumers so that companies can also increase brand loyalty to consumers. Eric Hariyanto explained in his research, brand experience has a significant effect on brand trust, brand experience has a significant effect on brand satisfaction, brand experience has a significant effect on brand loyalty, brand trust has a significant effect on brand loyalty, brand satisfaction has a significant effect on brand loyalty, brand satisfaction has a significant effect on brand trust [17]. So hopefully later if consumers already feel trust in a brand, can also deliver consumers to be loyal to the brand and it can last for a long time. In relationship - marketing literature, trust has been viewed as a determinant of the loyalty [22].

Brand trust in recent studies has been recognized as a key variable in long-term relationships with customers, which in turn positively affects brand loyalty. Brand trust leads to higher levels of loyalty as trust creates exchange relationships that are highly valued [29]. Brand trust leads to brand loyalty because trust creates exchange relationships that are highly valued". The relationship between trust and loyalty is deeprooted in the literature since Morgan and Hunt (1994). While trust is a key point in building and maintain customer relationships in products, it is of much importance in service marketing.
Loyalty and trust are key players if the aim to survive in a highly competitive market. This relationship should be taken seriously by mobile service operators. It is not only enough to measure and know whether customers trust companies or not, rather, what is more important is to measure customers' level of trust and know how customers trust evolve. Moreover, while loyalty is the aim of service providers, customers should be segmented on to how much they are loyal, accordingly marketing strategies could be directed properly to the right customer. From the results of the study that have been described by researchers, the researchers concluded that brand trust has an influence on brand loyalty [29]. This can happen because if consumers feel confident in a product/service of a company, then consumers will feel happy to make a purchase or use the same service for the second time and when it continues for a long period of time, then the consumer will be loyal.

Loyalty itself can be interpreted as a condition where consumers will be loyal to a product/service. Consumers who have high loyalty to a brand will tend to continue to choose the same brand even if there is a change from the form of packaging, to the price. But conversely, consumers who have low brand loyalty will tend to change their choices to others. Therefore, brand trust can affect brand loyalty because from that trust consumers will become loyal and not move to other products/services.

Preposition 3: Brand Trust has a significant effect on Brand Loyalty of Customers.

\section{CONCEPTUAL FRAMEWORK AND LIMITATIONS}

Based on the theories that have been explained, the researcher's conceptual framework in this study is illustrated from several variables that have been described, then illustrated in the Figure 1.

The limitation of this study lies in the lack of novelty of the theory used by researchers, and this study has not been empirically tested by researchers. So hopefully in the future, this research can be considered to be developed by future researchers. Researchers also hope that later this research can be empirically tested. According to the relevant theories, different types of consumers are different in each stage in terms of transparency, brand trust, brand satisfaction, and also brand loyalty. In short, there are many intermediary influence 
The $1^{\text {st }}$ International Conference on Business and Engineering Management (IConBEM)

February $1^{\text {st }} 2020$, Institut Teknologi Sepuluh Nopember, Surabaya, Indonesia

factors between transparency, brand trust, brand satisfaction and also brand loyalty which can be refined for different influencing factors. Different types of consumers can also be divided into different types. Therefore, the research on transparency, brand trust, brand satisfaction, and brand loyalty can be subdivided in many aspects, to obtain more comprehensive and in-depth research results.

\section{REFERENCES}

[1] I. K. Subagja and P. H. Susanto, "Pengaruh kualitas pelayanan, kepuasan nasabah dan citra perusahaan terhadap loyalitas nasabah Pt. Bank Central Asia Tbk Kantor Cabang Pondok Gede Plaza," J. Manaj. Bisnis Krisnadwipayana, vol. 7, no. 1, pp. 69-84, 2019, doi: $10.35137 /$ jmbk.v7i1.249.

[2] T. Suryani, Perilaku Konsumen di Era Internet Implikasinya pada Strategi Pemasaran. Graha Ilmu, 2014.

[3] S. A. Kasimba and P. Lujala, "There is no one amongst us with them! Transparency and participation in local natural resource revenue management," Extr. Ind. Soc., vol. 6, no. 1, pp. 198-205, 2019, doi: 10.1016/j.exis.2018.10.011.

[4] L. F. Ackert, B. K. Church, S. Venkataraman, and P. Zhang, "The joint impact of accountability and transparency on managers' reporting choices and owners' reaction to those choices," $J$. Account. Public Policy, vol. 38, no. 2, pp. 130-145, 2019, doi: 10.1016/j.jaccpubpol.2019.02.005.

[5] O. B. Albu and M. Flyverbom, "Organizational transparency: Conceptualizations, conditions, and consequences," Bus. Soc., vol. 58, no. 2, pp. 268-297, 2019, doi: 10.1177/0007650316659851.

[6] G. Christensen and E. Miguel, "Transparency, reproducibility, and the credibility of economics research," J. Econ. Lit., vol. 56, no. 3, pp. 920-980, 2018, doi: 10.1257/jel.20171350.

[7] A. Weller, "Transparency: Motivations and Challenges," in Explainable AI: Interpreting, Explaining and Visualizing Deep Learning. Lecture Notes in Computer Science, vol. 11700 LNCS, W. Samek, G. Montavon, A. Vedaldi, L. K. Hansen, and K.-R. Müller, Eds. Cham, Switzerland: Springer Verlag, 2019, pp. 2340.

[8] Y. Sutarso, R. E. Halim, T. E. Balqiah, and P. Tjiptoherijanto, "The role of co-creation activities, trust and gender on higher education marketing performance," Eur. Res. Stud. J., vol. XX, no. 3A, pp. 825-845, 2017, doi: 10.35808/ersj/748.

[9] S. Portal, R. Abratt, and M. Bendixen, "The role of brand authenticity in developing brand trust," J. Strateg. Mark., vol. 27, no. 8, pp. 714-729, 2019, doi: 10.1080/0965254X.2018.1466828.

[10] R. Saputra and C. K. Dewi, "The impact of brand trust on brand loyalty mediated by customer satisfaction: Case of Tokobagus.com (now OLX.co.id)," J. Adm. Bus. Stud., vol. 1, no. 1, pp. 8-13, 2016, doi: 10.20474/jabs-1.1.2.

[11] Y. Y. Dai, Q. Qin, and S. Ma, "Influence of travel enterprise public welfare marketing and brand attitude on brand trust," in EBDIT 2019: 2019 3rd International Workshop on Education, Big Data and Information Technology, 2019, pp. 107-112, doi: $10.1145 / 3352740.3352759$.

[12] M. Venter, R. Chinomona, and T. Chuchu, "The influence of store environment on brand trust, brand satisfaction and brand loyalty among the black middle class," Retail Mark. Rev., vol. 12, no. 2, pp. 46-58, 2016.

[13] A. C. Moreira, P. M. F. Da Silva, and V. M. Ferreira Moutinho, "The effects of brand experiences on quality, satisfaction and loyalty: An empirical study in the telecommunications multipleplay service market," Innovar, vol. 27, no. 64, pp. 23-38, 2017, doi: 10.15446/innovar.v27n64.62366.
[14] H. A. Mabkhot, S. M. Salleh, and H. Shaari, "The mediating effect of brand satisfaction on the relationship between brand personality and brand loyalty: Evidence from Malaysia," Manag. Sci. Lett., vol. 6, no. 1, pp. 87-98, 2016, doi: 10.5267/j.msl.2015.11.004.

[15] Y. Zhao, Y. Chen, R. Zhou, and Y. Ci, "Factors influencing customers' willingness to participate in virtual brand community's value co-creation: The moderating effect of customer involvement," Online Inf. Rev., vol. 43, no. 3, pp. 440-461, 2019, doi: 10.1108/OIR-08-2017-0232.

[16] C. Veloutsou, "Brand evaluation, satisfaction and trust as predictors of brand loyalty: the mediator-moderator effect of brand relationships," J. Consum. Mark., vol. 32, no. 6, pp. 405-421, 2015, doi: 10.1108/JCM-02-2014-0878.

[17] E. Hariyanto, "The influence of brand experience through brand trust and brand satisfaction toward brand loyalty consumer at Carl 's Jr Surabaya," Petra Bus. Manag. Rev., vol. 4, no. 2, pp. 19-29, 2018.

[18] A. N. Giovanis and P. Athanasopoulou, "Consumer-brand relationships and brand loyalty in technology-mediated services," J. Retail. Consum. Serv., vol. 40, pp. 287-294, 2018, doi: 10.1016/j.jretconser.2017.03.003.

[19] N. Gözükara, İ Çolakoğlu, "A Research on Generation Y Students $\backslash$ InBrand Innovation, Brand Trust and Brand Loyalty," Int. J. Bus. Manag. Econ. Res., vol. 7, no. 2, pp. 603-611, 2016.

[20] T. Shanahan, T. P. Tran, and E. C. Taylor, "Getting to know you: Social media personalization as a means of enhancing brand loyalty and perceived quality," J. Retail. Consum. Serv., vol. 47, pp. 57-65, 2019, doi: 10.1016/j.jretconser.2018.10.007.

[21] R. Pappu and P. G. Quester, "How does brand innovativeness affect brand loyalty?," Eur. J. Mark., vol. 50, no. 1-2, pp. 2-28, 2016, doi: 10.1108/EJM-01-2014-0020.

[22] D. S. Kumar and M. Lakshmibala, "Impact of perceived quality, brand image and brand trust on customer satisfaction and loyalty: A study of selected dairy production in Chennai," J. Gujarat Res. Soc., vol. 21, no. 14, pp. 1073-1083, 2019.

[23] J. Sasmita and N. Mohd Suki, "Young consumers' insights on brand equity: Effects of brand association, brand loyalty, brand awareness, and brand image," Int. J. Retail Distrib. Manag., vol. 43, no. 3, pp. 276-292, 2015, doi: 10.1108/IJRDM-02-2014-0024

[24] H. Kim and T. H. Lee, "Strategic CSR communication: A moderating role of transparency in trust building," Int. J. Strateg. Commun., vol. 12, no. 2, pp. 107-124, 2018, doi: 10.1080/1553118X.2018.1425692.

[25] X. Zu, W. Yu, and Y. Qiu, "Research on the impact of food safety crisis on brand trust: The mediating effect of enterprise information transparency," in 2018 International Conference on Economics, Finance, Business, and Development (ICEFBD 2018), 2018, pp. 185-191, doi: 10.25236/icefbd.18.041.

[26] J. Kang and G. Hustvedt, "Building trust between consumers and corporations: The role of consumer perceptions of transparency and social responsibility," J. Bus. Ethics, vol. 125, pp. 253-265, 2014, doi: 10.1007/s10551-013-1916-7.

[27] S. Gultom, D. Marlita, and A. Wardana, "Kualitas layanan, kepercayaan merek dan kepuasan penumpang," J. Manaj. Transp. Logistik, vol. 5, no. 2, pp. 169-178, 2018, doi: 10.25292/j.mtl.v5i2.248.

[28] Z. Qorbani, H. Koosha, and M. Bagheri, "The impact of brand equity on customer equity," in Proceedings of 2019 15th Iran International Industrial Engineering Conference, IIIEC 2019, 2019, pp. 212-222, doi: 10.1109/IIIEC.2019.8720728.

[29] R. A. El Naggar and N. Bendary, "The impact of experience and brand trust on brand loyalty, while considering the mediating effect of brand equity dimensions, an empirical study on mobile operator subscribers in Egypt.," Bus. Manag. Rev., vol. 9, no. 2, pp. 16-25, 2017 